\title{
Identifikasi miskonsepsi materi getaran dan gelombang pada siswa SMP kelas VIII menggunakan three-tier test
}

\author{
Merry Christiani, Munzil*, Erni Yulianti \\ Universitas Negeri Malang, Jl. Semarang No. 5 Malang, Jawa Timur, Indonesia \\ *Penulis korespondensi, Surel: munzil.fmipa@um.ac.id
}

Paper received: 01-04-2021; revised: 15-04-2021; accepted: 30-04-2021

\begin{abstract}
Abstrak
Ilmu Pengetahuan Alam (IPA) merupakan pengetahuan yang sistematis mengenai gejala-gejala alam yang ada berdasarkan hasil observasi, eksperimen, penyimpulan, dan penyusunan suatu teori. Miskonsepsi merupakan pemahaman oleh siswa tentang suatu konsep yang tidak sesuai dengan konsep ilmiah yang diterima oleh para ahli yang dapat mengakibatkan permasalahan pada siswa. Tes diagnostik digunakan untuk menentukan elemen-elemen pada suatu mata pelajaran yang memungkinkan adanya miskonsepsi, salah satunya menggunakan instrumen tes diagnostik threetier pada siswa. Penelitian ini menggunakan metode deskriptif kuantitatif dengan tujuan mengidentifikasi miskonsepsi konsep getaran dan gelombang pada siswa SMP kelas VIII menggunakan tes diagnostik three-tier. Berdasarkan hasil tes menggunakan three-tier diagnostic test dapat diketahui bahwa persentase tertinggi miskonsepsi siswa materi getaran dan gelombang sebanyak 54,94 persen yakni pada konsep gerak gelombang.
\end{abstract}

Kata kunci: Miskonsepsi; Getaran dan Gelombang; Three-Tier Test

\section{Pendahuluan}

Ilmu Pengetahuan Alam (IPA) merupakan pengetahuan yang sistematis mengenai gejala-gejala alam yang ada berdasarkan hasil observasi, eksperimen, penyimpulan, dan penyusunan suatu teori. Sebagai produk, IPA merupakan kumpulan pengetahuan, konsep dan bagan konsep. Konsep dalam IPA bersifat abstrak dan sulit untuk dipahami siswa (Marlina dkk, 2017). Kesulitan dalam mempelajari konsep abstrak ini dapat menyebabkan siswa mengalami miskonsepsi.

Miskonsepsi merupakan pemahaman oleh siswa tentang suatu konsep yang tidak sesuai dengan konsep ilmiah yang diterima oleh para ahli (Zayyinah dkk, 2018). Miskonsepsi dapat terjadi karena berbagai penyebab antara lain berasal dari siswa, pengajar, buku teks, konteks, dan cara mengajar (Sarlina, 2015). Selain dapat disebabkan oleh pengetahuan awal siswa, miskonsepsi dapat disebabkan oleh pengalaman lingkungan sehari-hari siswa yang tidak sesuai dengan konsep IPA (Dewi dkk, 2016).

Miskonsepsi mengakibatkan permasalahan pada siswa seperti kesulitan dalam mengolah suatu informasi baru yang menjadikan siswa kebingungan dan mengalami kesalahpahaman konsep. Pemahaman konsep yang tidak tepat secara terus menerus akan mempengaruhi efektifitas proses belajar siswa (Abbas, 2016). Identifikasi pada siswa sangat perlu dilakukan untuk mengetahui seberapa besar miskonsepsi yang terjadi sehingga dapat segera diminimalisir dan tidak terjadi miskonsepsi berkelanjutan (Shalihah dkk, 2016).

Tes diagnostik digunakan untuk menentukan elemen-elemen pada suatu mata pelajaran yang mungkin adanya miskonsepsi. Proses pengumpulan informasi yang berkaitan dengan miskonsepsi dapat digunakan interview, open-ended test, multiple-choice test, multiple-tier test yakni two-tier, three-tier, four-tier dan lainnya (Gurel dkk, 2015). Masingmasing tes memiliki kelebihan di setiap hasil identifikasinya. Menurut Pesman (2005) dan 
Ratnaningdyah (2018), pengidentifikasian menggunakan tes diagnostik three-tier memiliki keuntungan yang lebih dibandingkan two-tier, karena mampu membedakan siswa yang kurang tingkat pengetahuan konsepnya berdasarkan pada keyakinan siswa dalam memberikan jawaban di tier pertama dan tier kedua atas permasalahan yang disajikan.

Hasil UN SMP tahun 2019 menurut data PUSPENDIK untuk wilayah Jawa Timur menunjukkan bahwa penguasaan materi IPA khususnya gelombang mencapai 37,32\% dan $31,74 \%$ untuk skala nasional. Persentase ini menunjukkan bahwa masih adanya miskonsepsi pada siswa. Berdasarkan hasil penelitian sebelumnya menunjukkan bahwa siswa mengalami miskonsepsi pada konsep getaran, gelombang transversal, gelombang longitudinal, hubungan antara panjang gelombang dengan jarak tempuh gelombang dan hubungan antara periode dengan amplitudo serta frekuensi gelombang (Liza dkk, 2016; Istiqomah dkk, 2017).

Hasil studi pendahuluan melalui wawancara dengan guru IPA di salah satu SMP kota Malang, diketahui bahwa banyak siswa yang mengalami miskonsepsi pada materi getaran dan gelombang. Guru mengidentifikasi miskonsepsi yang terjadi melalui analisis jawaban siswa dari hasil belajar siswa dan pengamatan selama proses pembelajaran berlangsung. Berdasar pada tes yang digunakan yakni tes pilihan ganda, guru tidak dapat menentukan bagian-bagian materi yang menjadi miskonsepsi.

Penelitian ini bertujuan mengidentifikasi miskonsepsi konsep getaran dan gelombang pada siswa SMP kelas VIII menggunakan tes diagnostik three-tier. Diharapkan hasil penelitian ini dapat menjadi penambah wawasan mengenai bagian-bagian pada materi getaran dan gelombang yang sering terjadi miskonsepsi.

\section{Metode}

Metode penelitian ini adalah deskriptif kuantitatif. Subyek penelitian ini adalah siswa kelas VIII A dan VIII D di SMP PGRI 01 Wagir, Kabupaten Malang dengan jumlah siswa sebanyak 54 siswa. Metode pengumpulan data dalam penelitian ini menggunakan tes diagnostik berupa pilihan ganda bertingkat tiga/ three-tier test. Tes yang digunakan yakni tes diagnostik three-tier sejumlah 26 butir yang telah dikembangkan oleh Muhammad Ainal Yaqin dengan reliabilitas sebesar 0,814 (sangat tinggi). Prosedur penelitian ini dibagi menjadi tiga tahap, yakni tahap persiapan, tahap pelaksanaan, dan tahap analisis data untuk mengidentifikasi miskonsepsi siswa. Hasil analisis data kemudian dijadikan dasar penarikan kesimpulan yang berkaitan dengan miskonsepsi pada materi getaran dan gelombang. Berikut kombinasi pola jawaban dan kategori jawaban yang disajikan sebagai pedoman kategori jawaban siswa pada Tabel 2.1.

Tabel 2.1 Pedoman Kategori Jawaban Siswa

\begin{tabular}{lllll}
\hline $\begin{array}{l}\text { Tier } \\
\text { Pertama }\end{array}$ & $\begin{array}{l}\text { Tier } \\
\text { Kedua }\end{array}$ & $\begin{array}{l}\text { Tier } \\
\text { Ketiga }\end{array}$ & Kategori & Kode \\
\hline Benar & Benar & Yakin & Paham konsep & PK \\
\hline Benar & Benar & Tidak yakin & $\begin{array}{l}\text { Tidak paham } \\
\text { konsep }\end{array}$ & TPK \\
\hline Benar & Salah & Yakin & False Positive & FP \\
\hline Benar & Salah & Tidak yakin & $\begin{array}{l}\text { Tidak paham } \\
\text { konsep }\end{array}$ & TPK \\
\hline Salah & Benar & Yakin & False negative & FN \\
\hline
\end{tabular}




\begin{tabular}{ccclc}
\hline Salah & Benar & Tidak yakin & $\begin{array}{l}\text { Tidak paham } \\
\text { konsep }\end{array}$ & TPK \\
\hline Salah & Salah & Yakin & Miskonsepsi & MK \\
\hline Salah & Salah & Tidak yakin & $\begin{array}{l}\text { Tidak paham } \\
\text { konsep }\end{array}$ & TPK \\
\hline & (Pesman \& Eryilmaz, 2010)
\end{tabular}

Kondisi false positive dan false negative menunjukkan adanya miskonsepsi, sehingga ada tiga tipe miskonsepsi. Tipe pertama yakni kondisi false positive, tipe kedua yakni kondisi false negative, dan kondisi ketiga yakni saat siswa menjawab salah pada tier pertama, tier kedua dan menjawab yakin pada tier ketiga terhadap jawaban yang telah diberikan pada 2 tier sebelumnya (Pesman \& Eryilmaz, 2010).

$$
\mathrm{P}=\frac{\mathrm{S}}{\mathrm{J} s} \times 100 \%
$$

Analisis untuk mengetahui persentase siswa yang paham konsep, tidak paham konsep, dan miskonsepsi menggunakan teknik persentase.

\section{Keterangan:}

$\mathrm{P}=$ Persentase jumlah siswa pada kategori paham konsep, tidak paham konsep, false positive, false negative, miskonsepsi

S = Banyaknya siswa pada kategori paham konsep, tidak paham konsep, false positive, false negative, miskonsepsi

Js = Jumlah seluruh siswa peserta tes

\section{Hasil dan Pembahasan}

Berdasarkan hasil tes diagnostik menggunakan three-tier diagnostic test, dapat diketahui persentase pemahaman konsep yakni paham konsep (PK), tidak paham konsep(TPK), false positive (FP), false negative (FN), dan miskonsepsi (MK) yang ditunjukkan pada Tabel 3.1.

Tabel 3.1 Persentase Kondisi Konsepsi Siswa Berdasarkan Three-Tier Test (\%)

\begin{tabular}{|c|c|c|c|c|c|}
\hline Konsep & PK & TPK & $F P$ & $F N$ & MK \\
\hline Getaran & 7,87 & 18,06 & 10,19 & 26,39 & 37,50 \\
\hline $\begin{array}{l}\text { Besaran } \\
\text { Gelombang }\end{array}$ & 15,61 & 23,54 & 14,55 & 12,70 & 33,60 \\
\hline $\begin{array}{l}\text { Gerak } \\
\text { Gelombang } \\
\text { Cepat }\end{array}$ & 3,70 & 16,05 & 10,49 & 14,81 & 54,94 \\
\hline $\begin{array}{l}\text { Rambat } \\
\text { Gelombang } \\
\text { Medium }\end{array}$ & 12,50 & 29,40 & 14,12 & 6,71 & 37,27 \\
\hline $\begin{array}{l}\text { Rambatan } \\
\text { Bunyi }\end{array}$ & 23,15 & 22,22 & 23,15 & 8,33 & 23,15 \\
\hline
\end{tabular}


Hasil pengumpulan data, jawaban siswa dengan kategori miskonsepsi, false positive, dan false negative dianalisis tiap konsep secara deskriptif. Miskonsepsi siswa berada pada tingkat yang berbeda tiap konsepnya. False positive tertinggi sebanyak $23,15 \%$ dialami siswa pada konsep medium rambatan bunyi. False negative tertinggi sebanyak 26,39\% dialami siswa pada konsep getaran. Miskonsepsi tertinggi sebanyak 54,94\% dialami siswa pada konsep gerak gelombang.

Berdasarkan data yang diperoleh, setiap konsep dalam materi getaran dan gelombang ditemukan persentase miskonsepsi yang berbeda-beda. Beberapa konsep dengan siswa $100 \%$ miskonsepsi, yakni seorang siswa pada konsep besaran gelombang, 11 siswa pada konsep gerak gelombang, dan seorang siswa pada konsep cepat rambat gelombang. Ada seorang siswa 100\% paham konsep namun hanya pada konsep medium rambatan bunyi.

\subsection{Konsep Getaran}

Getaran adalah peristiwa bolak-balik suatu benda melewati titik kesetimbangannya. Berikut persentase kriteria jawaban siswa yang ditunjukkan pada Gambar 3.1.

\section{Gambar 3.1. Persentase Kriteria Jawaban Siswa pada Konsep Getaran}

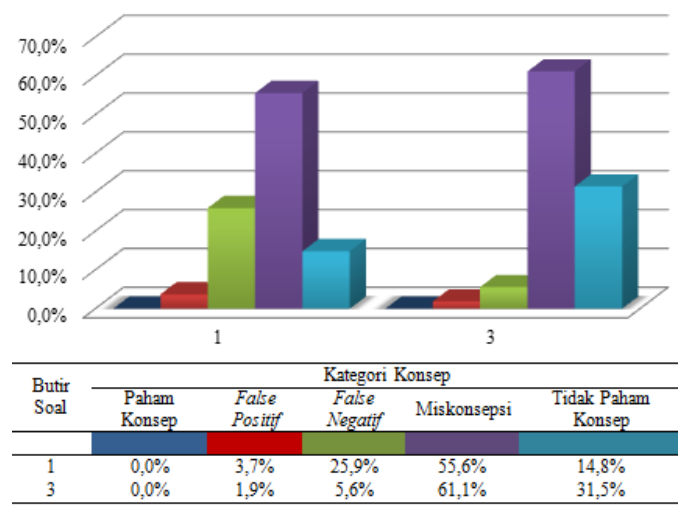

Konsep ini diwakilkan dalam butir soal nomor 1 dan 3 tes diagnostik. Hasil analisis jawaban siswa pada butir soal nomor 1 mengenai perbedaan panjang tali terhadap frekuensi dan periode getaran bandul, teridentifikasi sebanyak 55,6\% siswa miskonsepsi.

\section{Gambar 3.2. Butir Soal Nomor 1 mengenai Konsep Getaran}

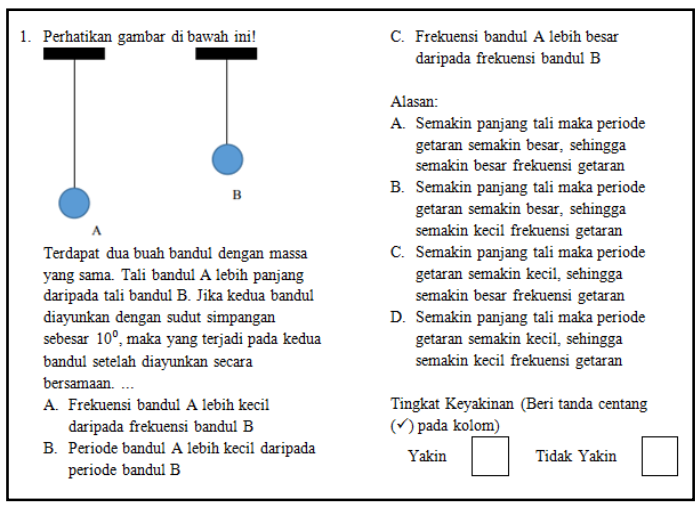


Siswa beranggappan bahwa semakin panjang tali bandul maka periode getaran bandul semakin kecil dan frekuensi bandul semakin besar.

Pada butir soal nomor 3, sebanyak 61,1\% siswa miskonsepsi dengan beranggapan bahwa perubahan massa bandul mempengaruhi perubahan periode getaran bandul.

\section{Gambar 3.3. Butir Soal Nomor 3 mengenai Konsep Getaran}

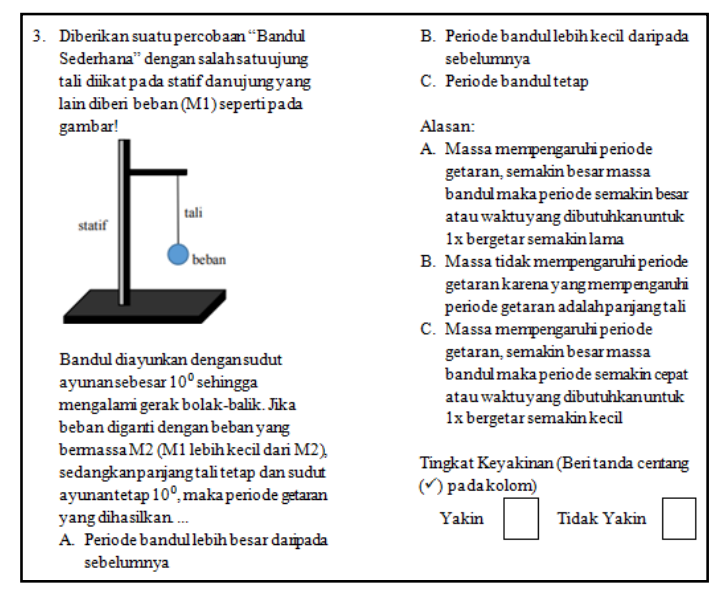

Kedua konsep siswa tersebut tidak sesuai dengan konsep ilmiah yakni periode dan frekuensi getaran dipengaruhi oleh panjang tali dan percepatan gravitasi (Serway \& Jewett, 2010). Sehingga perubahan massa bandul tidaklah berpengaruh terhadap perubahan periode getaran bandul.

\subsection{Konsep Besaran Gelombang}

Konsep besaran gelombang terbagi menjadi 2 yakni gelombang transversal dan gelombang longitudinal. Konsep gelombang transversal diwakilkan dalam butir soal nomor 6 dan 7. Berikut persentase kriteria jawaban siswa yang ditunjukkan pada Gambar 3.4.

Gambar 3.4. Persentase Kriteria jawaban Siswa pada Konsep Besaran Gelombang Transversal

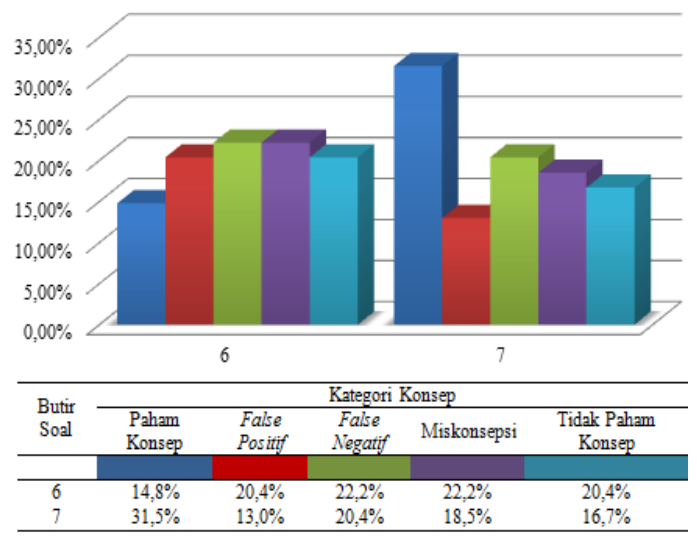


Hasil analisis jawaban siswa pada butir soal nomor 6 mengenai grafik gelombang terhadap jarak tempuh gelombang menunjukkan sebanyak $22,2 \%$ siswa mengalami miskonsepsi.

\section{Gambar 3.5. Butir soal Nomor 6 mengenai Konsep Besaran gelombang}

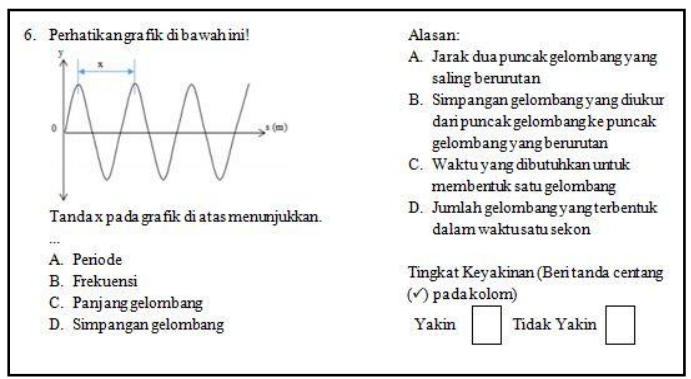

Siswa miskonsepsi dengan anggapan bahwa tanda "X" yang tertera pada grafik merupakan frekuensi dengan alasan simpangan gelombang yang diukur dari puncak gelombang ke puncak gelombang yang berurutan.

Hasil analisis jawaban siswa pada butir soal nomor 7 yakni mengenai frekuensi gelombang transversal yang ditentukan berdasarkan sajian data percobaan.

\section{Gambar 3.6. Butir Soal Nomor 7 mengenai Konsep Besaran Gelombang}
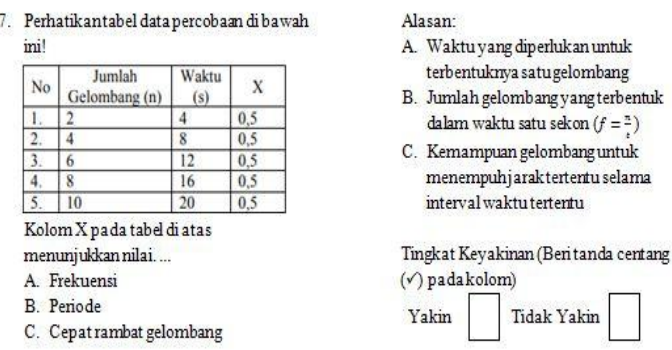

Sebanyak 20,4\% siswa mengalami false negative yakni siswa salah menjawab pada tier 1 namun benar dalam memberikan alasan pada tier 2. Siswa memberikan alasan bahwa jumlah gelombang yang terbentuk dalam waktu satu sekon $\left(\mathrm{f}=\frac{n}{t}\right)$.

Konsep gelombang longitudinal diwakilkan dalam butir soal nomor 8 dan 9 . Berikut persentase kriteria jawaban siswa. 


\section{Gambar 3.7. Persentase Kriteria Jawaban Siswa pada Konsep Besaran Gelombang Longitudinal}

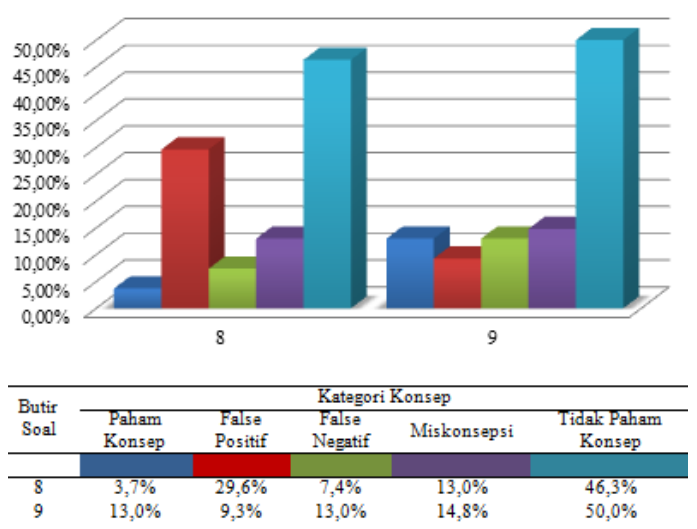

Hasil analisis jawaban siswa dalam butir soal nomor 8 mengenai pergerakan partikel pada batang. Sebanyak $29,6 \%$ siswa mengalami false positive, $13 \%$ siswa mengalami miskonsepsi dan $46,3 \%$ siswa tidak paham konsep.

\section{Gambar 3.8. Butir Soal Nomor 8 mengenai Konsep Besaran Gelombang}

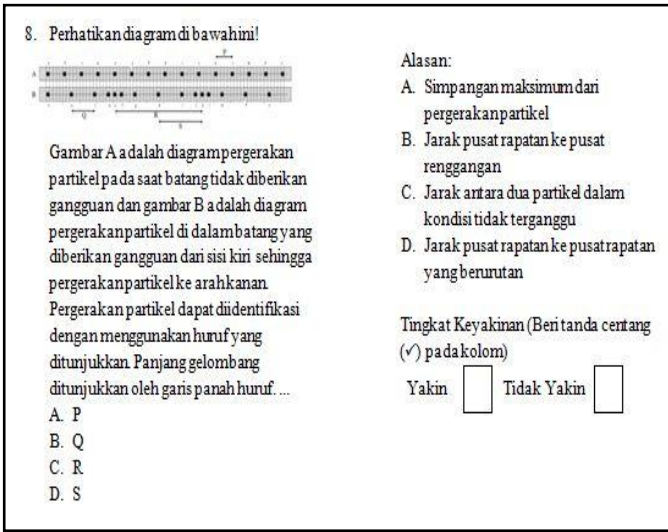

Hal ini ditunjukkan oleh 10 siswa menganggap bahwa panjang gelombang adalah simpangan maksimum pergerakan partikel, 21 siswa menganggap bahwa panjang gelombang adalah jarak pusat rapatan ke pusat renggangan, dan 11 siswa menganggap bahwa panjang gelombang adalah jarak antara dua partikel dalam kondisi tidak terganggu.

Berikut hasil analisis jawaban siswa pada butir soal nomor 9 mengenai identifikasi amplitudo gelombang longitudinal dalam diagram pergerakan partikel pada batang yang telah disajikan. 


\section{Gambar 3.9. Butir Soal Nomor 9 mengenai Konsep Besaran Gelombang}

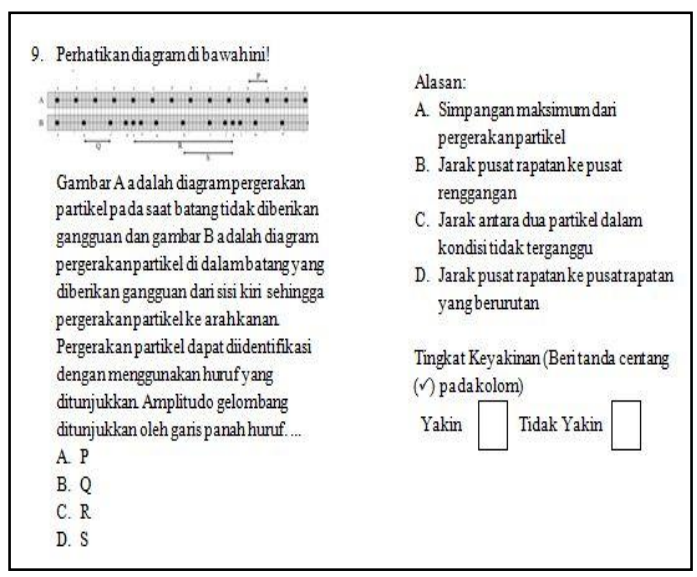

Bahwa sebanyak 14,8\% siswa mengalami miskonsepsi dan sebanyak 50\% siswa mengalami tidak paham konsep. Hal ini ditunjukkan pada hasil jawaban siswa yakni sebanyak 21 siswa menganggap amplitudo gelombang adalah jarak pusat rapatan ke pusat renggangan sedang 10 siswa lainnya menganggap amplitudo gelombang adalah jarak pusat rapatan ke pusat rapatan yang berurutan.

Persentase miskonsepsi yang terlihat menunjukkan tidak konsistennya pemahaman konsep yang dimiliki siswa akan konsep tersebut. Pada konsep besaran gelombang diperoleh rerata sebanyak 33,6\% siswa mengalami miskonsepsi. Konsep yang benar mengenai besaran gelombang, antara lain: bahwa panjang gelombang pada gelombang transversal adalah jarak minimum antara dua titik yang identik pada gelombang yang saling berurutan/bersebelahan; panjang gelombang pada gelombang longitudinal adalah jarak pusat rapatan ke pusat rapatan yang berurutan atau penjumlahan panjang satu area rapatan dan satu area renggangan (Serway \& Jewett, 2010); amplitudo merupakan simpangan maksimum dari pergerakan partikel atau perpindahan maksimum dari kesetimbangan suatu partikel; dan frekuensi adalah banyaknya gelombang yang terbentuk dalam satu satuan waktu.

\subsection{Konsep Gerak Gelombang}

Konsep gerak gelombang diwakilkan dalam butir soal nomor 13 dan 14. Pada konsep gerak gelombang diperoleh hasil menunjukkan 54,94\% siswa mengalami miskonsepsi. Berikut persentase kriteria jawaban siswa pada konsep gerak gelombang. 


\section{Gambar 3.10. Persentase Kriteria Jawaban Siswa pada Konsep Gerak Gelombang}

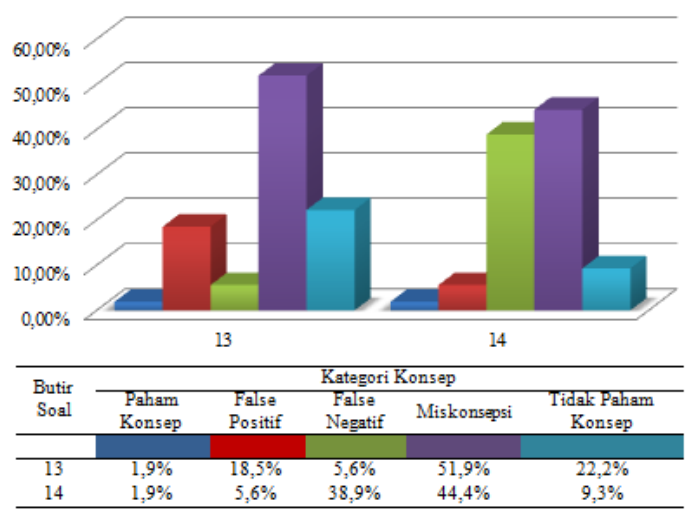

Hasil analisis menunjukkan siswa mengalami miskonsepsi sebanyak 51,9\% pada butir soal nomor 13 dan sebanyak 44,4\% pada butir soal nomor 14 . Sebagian banyak siswa beranggapan bahwa gelombang mekanik memindahkan materi.

\section{Gambar 3.11. Butir Soal Nomor 13 mengenai Konsep Gerak Gelombang}

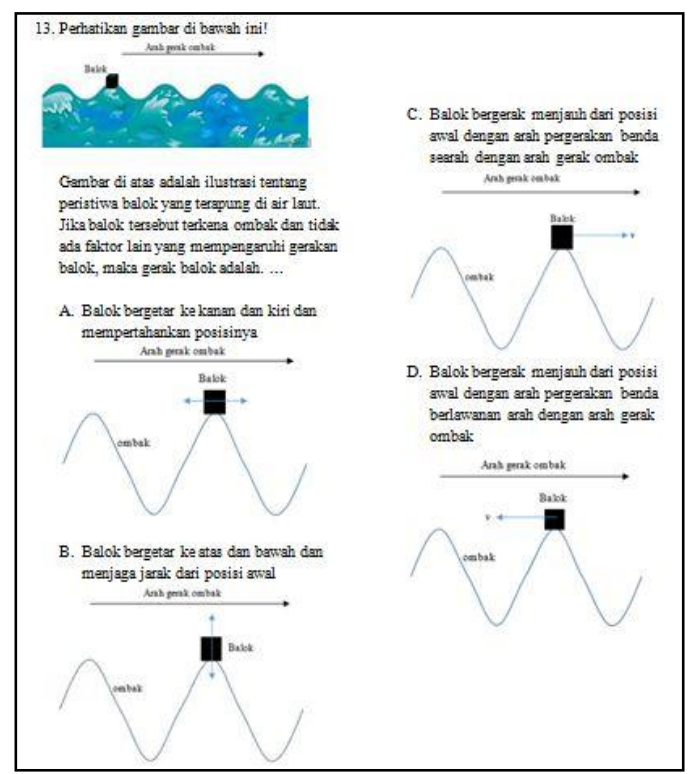

Pada butir soal nomor 13, miskonsepsi siswa yakni bahwa jika balok yang terapung di air laut terkena ombak, maka gerak balok bergetar ke kanan dan kiri dan mempertahankan posisinya. Alasan yang diberikan yakni gelombang membawa energi dari satu tempat ke tempat lain, energi dipindahkan sebagai energi getaran pada partikel-partikel mediumnya dan tidak memindahkan materi. Gelombang laut (ombak laut) menggetarkan balok ke kanan dan kiri karena termasuk gelombang longitudinal yang arah getarnya sejajar dengan arah gerak ombak.

Hasil analisis pada butir soal nomor 14, sebanyak 38,9\% siswa mengalami false negative sedangkan 44,4\% siswa miskonsepsi. Berdasarkan jawaban siswa, gelombang menggetarkan medium rambatannya dan memindahkan materi. Sehingga siswa beranggapan bahwa ketika daun yang berada di permukaan air terkena riak (gelombang) maka daun akan bergetar ke atas dan bawah hingga ke tepi kolam. 


\section{Gambar 3.12. Butir Soal Nomor 14 mengenai Konsep Gerak Gelombang}

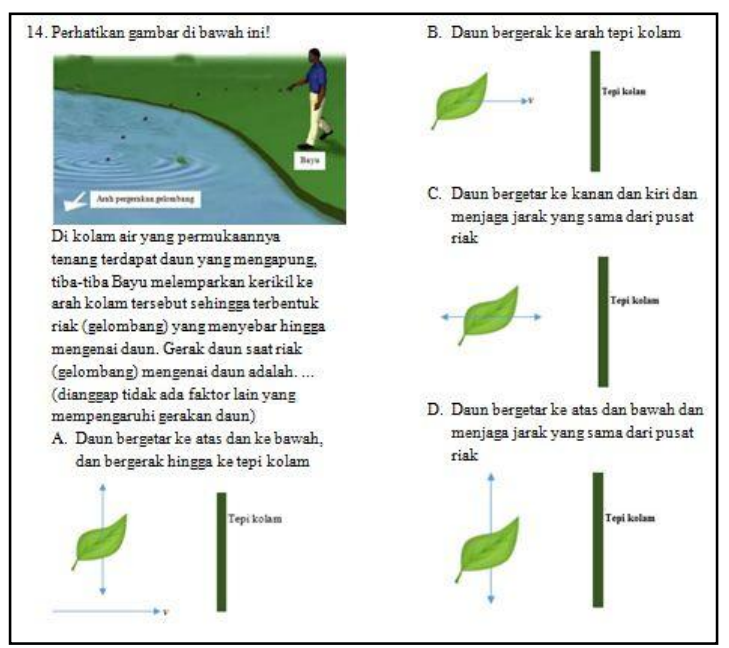

Siswa telah memahami bahwa gelombang membawa energi dari satu tempat ke tempat lain, energi yang dipindahkan sebagai energi getaran pada partikel-partikel mediumnya dan tidak memindahkan materi. Daun bergetar ke atas dan bawah karena merupakan gelombang transversal yang arah getarnya tegak lurus dengan arah pergerakan gelombang. Meskipun demikian, berdasarkan sebagian banyak jawaban siswa, teridentifikasi miskonsepsi bahwa gelombang mekanik memindahkan materi. Konsep yang benar ketika daun di permukaan air terkena riak, daun bergerak ke atas dan bawah dimana gelombang memindahkan energi dengan menggetarkan mediumnya, tidak memindahkan materinya (Serway \& Jewett, 2010).

Siswa mengalami miskonsepsi terbanyak yakni 40,12\%. Miskonsepsi siswa yakni gelombang yang dalam perambatannya memindahkan materi sehingga partikel mediumnya terdorong ke segala arah dari sumber gelombang. Konsep yang benar bahwa gelombang mekanik memindahkan energi dengan menggetarkan medium rambatannya (Serway \& Jewett, 2010).

\subsection{Konsep Cepat Rambat Gelombang}

Konsep cepat rambat gelombang terbagi menjadi dua subkonsep. Sub konsep pertama yakni konsep cepat rambat gelombang tali yang diwakili oleh butir soal nomor 18, 19, dan 21. Berikut persentase kriteria jawaban siswa pada konsep cepat rambat gelombang tali. 


\section{Gambar 3.13. Persentase Kriteria Jawaban Siswa pada Konsep Cepat Rambat Gelombang Tali}

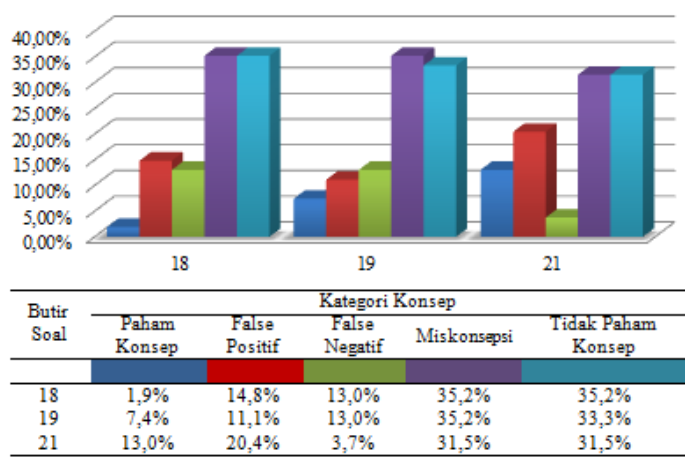

Hasil analisis jawaban pada butir soal nomor 18, sebanyak 35,2\% siswa mengalami miskonsepsi dan 35,2\% siswa tidak paham konsep. Sebanyak 29 siswa teridentifikasi mengalami miskonsepsi yakni adanya anggapan bahwa jika salah satu ujung tali disentakkan dengan lebih kuat sehingga amplitudonya bertambah, tetapi frekuensi gelombang tetap, maka cepat rambat gelombang yang dihasilkan akan lebih cepat dari sebelumnya. Konsep yang benar, ketika tegangan tali tetap, massa jenis tali tetap maka cepat rambat gelombang tetap.

\section{Gambar 3.14. Butir Soal Nomor 18 mengenai Konsep Cepat Rambat Gelombang}

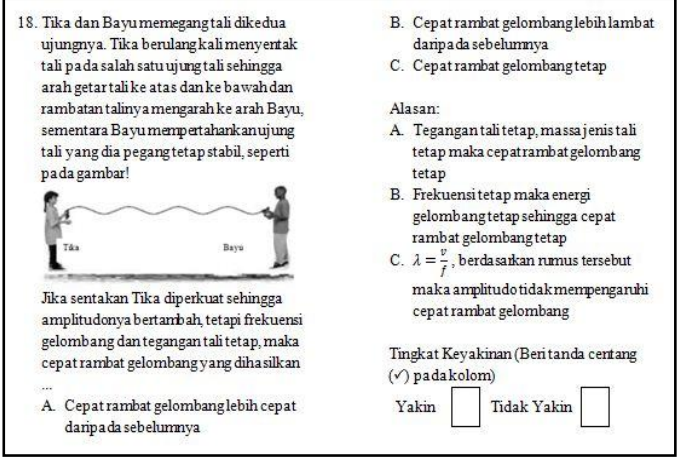

Pada butir soal nomor 19 mengenai pengaruh massa tali terhadap cepat rambat gelombang, diperoleh hasil jawaban siswa bahwa sebanyak 35,2\% siswa mengalami miskonsepsi. 


\section{Gambar 3.15. Butir Soal Nomor 19 mengenai Konsep Cepat Rambat Gelombang}

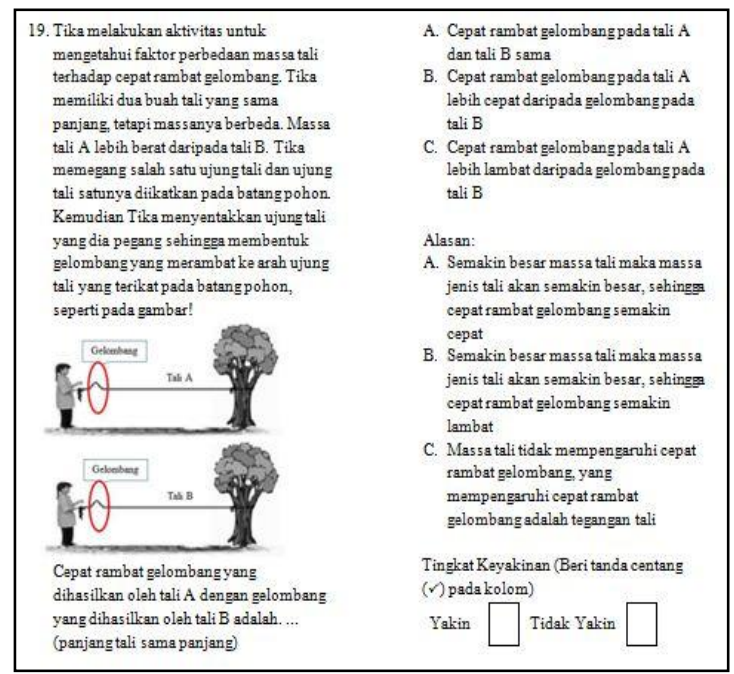

Pada butir soal 19, siswa diharapkan dapat menganalisis massa jenis tali terhadap cepat rambat gelombang pada sajian gambar aktivitas seorang anak sedang bermain dengan dua buah tali yang sama panjang tetapi berbeda massa, massa tali $\mathrm{A}$ lebih berat daripada tali B. Saat bermain, salah satu ujung dari kedua tali diikatkan pada batang pohon dan ujung tali lainnya dipegang hingga tegangan tali sama. Miskonsepsi siswa beranggapan bahwa cepat rambat gelombang pada tali A lebih cepat daripada gelombang pada tali B ketika ujung tali yang dipegang disentakkan. Konsep yang benar, semakin besar massa tali maka massa jenis tali akan semakin besar, sehingga cepat rambat gelombang akan semakin lambat (Serway \& Jewett, 2010).

\section{Gambar 3.16. Butir Soal Nomor 21 mengenai Konsep Cepat Rambat Gelombang}
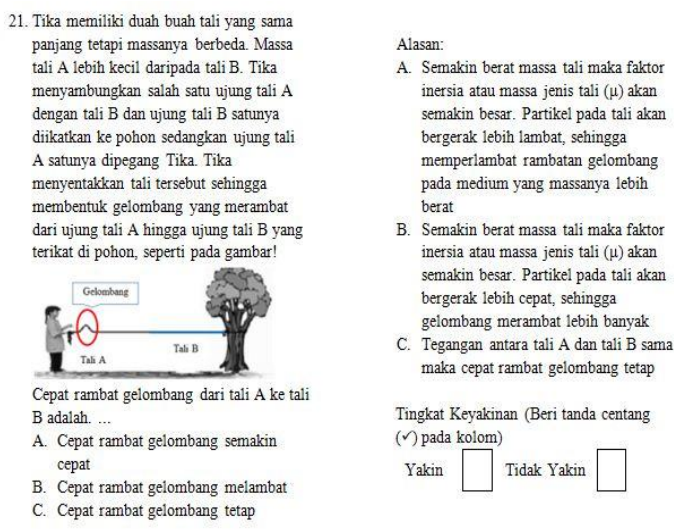

Pada butir soal nomor 21 mengenai hubungan antara panjang gelombang, frekuensi, cepat rambat gelombang dan periode gelombang. Sebanyak 31,5\% siswa mengalami miskonsepsi. Miskonsepsi siswa yakni semakin berat massa tali maka faktor inersia atau massa jenis tali $(\mu)$ akan semakin besar. Partikel pada tali akan bergerak lebih cepat sehingga gelombang merambat lebih banyak. Konsep yang benar, semakin berat massa tali maka faktor inersia atau massa jenis tali $(\mu)$ akan semakin besar. Partikel pada tali akan bergerak lebih lambat sehingga memperlambat 
rambatan gelombang pada medium yang massanya berbeda. Gelombang merambat dari medium yang lebih renggang menuju medium yang lebih rapat maka cepat rambat gelombang akan berkurang atau melambat ( Serway \& Jewett, 2010).

Sub konsep kedua yakni konsep cepat rambat gelombang terhadap jarak dan waktu tempuh gelombang yang diwakili oleh butir soal nomor 15 dan 22. Berikut persentase kriteria jawaban siswa pada konsep cepat rambat gelombang terhadap jarak dan waktu tempuh gelombang.

\section{Gambar 3.17. Persentase Kriteria Jawaban Siswa pada Konsep Cepat Rambat Gelombang terhadap Jarak dan Waktu Tempuh Gelombang}

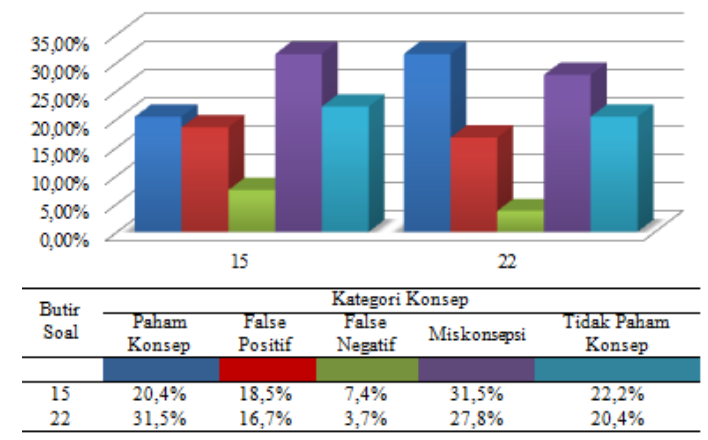

Hasil analisis jawaban pada butir soal nomor 15, sebanyak 31,5\% siswa mengalami miskonsepsi. Butir soal ini mengenai subkonsep cepat rambat gelombang terhadap waktu tempuh gelombang dengan bahasan perbedaan frekuensi dari dua sumber bunyi terhadap waktu dan jarak tempuhnya oleh pendengar.

Gambar 3.18. Butir Soal Nomor 15 mengenai Konsep Cepat Rambat Gelombang

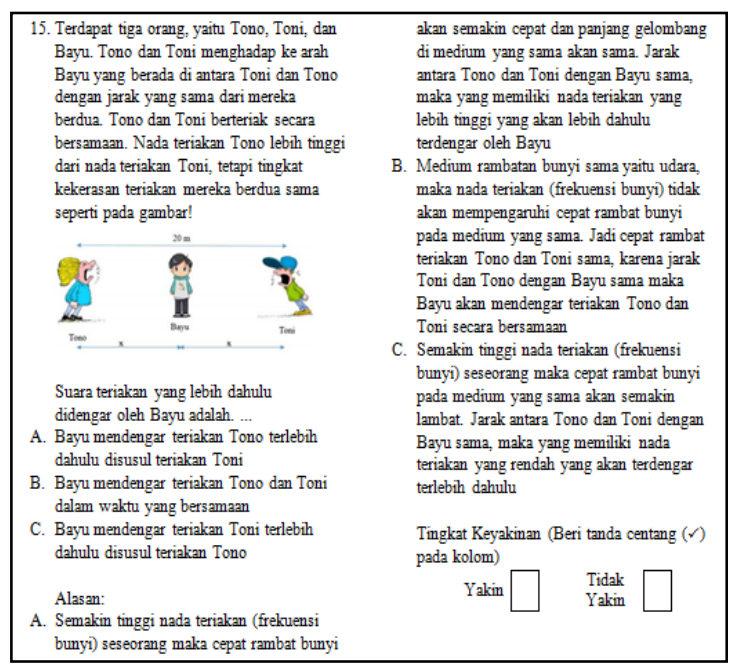

Miskonsepsi siswa yang teridentifikasi bahwa siswa beranggapan semakin tinggi nada teriakan (frekuensi bunyi) seseorang maka cepat rambat bunyi akan semakin cepat dan panjang gelombang di medium yang sama akan sama. Jarak antara Tono dan Toni dengan Bayu sama, maka yang memiliki nada teriakan yang lebih tinggi yang akan lebih dahulu terdengar oleh Bayu. Konsep yang benar apabila terdapat dua sumber bunyi dengan medium yang sama yakni udara dimana kerapatan medium 
sama maka cepat rambat gelombang bunyi yang dihasilkan oleh dua sumber bunyi adalah sama. Jika cepat rambat bunyi sama, jarak antara pendengar dan kedua sumber bunyi sama maka bunyi dari kedua sumber bunyi akan terdengar bersamaan oleh pendengar. Jika cepat rambat sama dan frekuensi berbeda maka panjang gelombang dari kedua sumber bunyi berbeda. Semakin tinggi frekuensi gelombang maka panjang gelombang semakin pendek pada kondisi cepat rambat yang tetap. Hubungan ketiganya adalah sebagai berikut.

$$
\lambda=\frac{v}{f}
$$

(Serway \& Jewett, 2010)

Hasil analisis jawaban pada butir soal nomor 22 mengenai pengaruh faktor panjang tali terhadap cepat rambat dan waktu tempuh gelombang, sebanyak $27,8 \%$ siswa mengalami miskonsepsi.

\section{Gambar 3.19. Butir Soal Nomor 22 mengenai Konsep Cepat Rambat Gelombang}
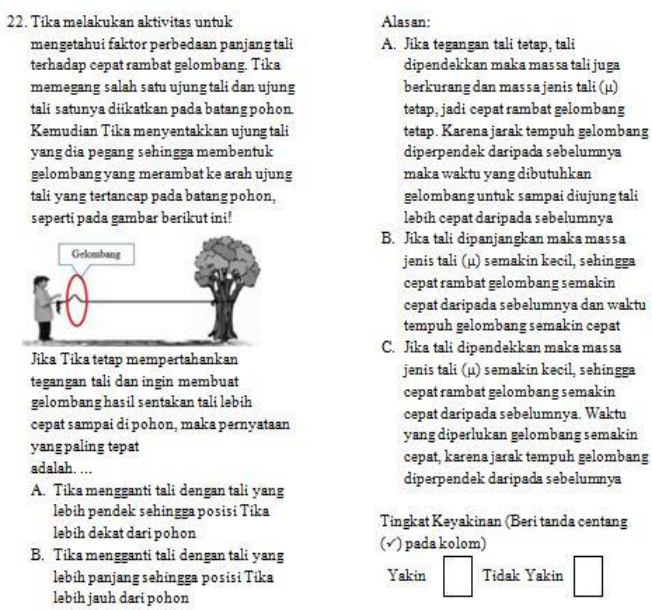

Siswa teridentifikasi miskonsepsi sebab beranggapan bahwa jika tetap mempertahankan tegangan tali dan ingin membuat gelombang hasil sentakan tali lebih cepat sampai di pohon, maka perlu mengganti tali yang lebih panjang sehingga posisi menjauhi pohon. Pada konsepnya, jika tegangan tali tetap, tali dipendekkan maka massa tali juga berkurang dan massa jenis tali $(\mu)$ tetap, maka cepat rambat gelombang tetap. Ketika jarak tempuh gelombang diperpendek maka waktu yang dibutuhkan gelombang untuk sampai di ujung tali lebih cepat daripada sebelumnya. Sesuai konsep yang benar, baiknya tali perlu diganti dengan yang lebih pendek sehingga posisi lebih dekat dengan pohon.

Konsep mengenai cepat rambat gelombang, antara lain bahwa ketika tegangan tali tetap dan massa jenis tali tetap maka cepat rambat gelombang adalah tetap; semakin besar massa tali maka massa jenis tali akan semakin besar, sehingga cepat rambat gelombang akan semakin lambat; semakin tinggi frekuensi gelombang maka panjang gelombang semakin pendek pada kondisi cepat rambat yang tetap; gelombang merambat dari medium yang lebih renggang menuju medium yang lebih rapat maka 
cepat rambat gelombang akan berkurang atau melambat (Serway \& Jewett, 2010); serta ketika jarak tempuh gelombang diperpendek maka waktu yang dibutuhkan gelombang untuk sampai di ujung tali lebih cepat daripada sebelumnya.

\subsection{Konsep Medium Rambatan Bunyi}

Konsep siswa mengenai medium rambatan bunyi diidentifikasi berdasarkan jawaban siswa pada butir soal nomor 23 dan 24. Berikut persentase kriteria jawaban siswa.

\section{Gambar 3.20. Persentase Kriteria Jawaban Siswa pada Konsep Medium Rambatan Bunyi}

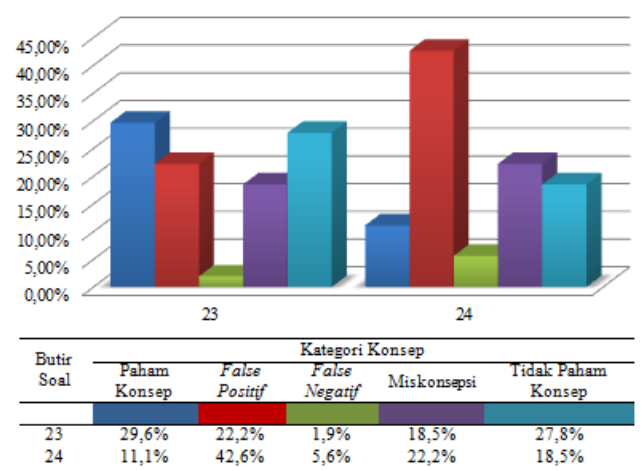

Hasil analisis jawaban siswa pada butir soal nomor 23, sebanyak 27,8\% siswa tidak paham konsep dan sebanyak $22,2 \%$ siswa mengalami false positive. Siswa mengalami miskonsepsi mengenai zat padat sebagai medium perambatan bunyi. Sebanyak 34 siswa mengetahui, benar pria di ruang B mendengar suara wanita yang sedang bernyanyi di ruang A. Namun siswa menganggap bahwa bunyi terebut merambat melalui udara dan celah antar ruangan sehingga tedengar oleh pria di ruang $\mathrm{B}$.

Dijelaskan pada gambar bahwa kedua ruangan dengan kondisi terisolasi atau tidak terdapat celah yang memungkinkan adanya perpindahan udara antar kedua ruangan. Sehingga mekanisme terdengarnya bunyi dari kedua ruangan tersebut yaitu bunyi dari pengeras suara dirambatkan melalui udara di ruang A, sebagian dipantulkan oleh tembok dan sebagian dirambatkan oleh tembok kemudian merambat melalui udara di ruang $\mathrm{B}$ dan terdengar oleh si pria.

\section{Gambar 3.21. Butir Soal Nomor 23 mengenai Konsep Medium Rambatan Bunyi}
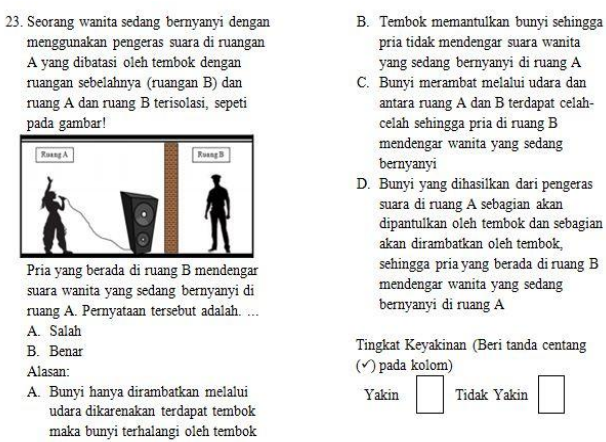
Butir soal nomor 24 mengenai perbandingan bunyi yang merambat pada tongkat (medium padat) dan medium udara.

\section{Gambar 3.22. Butir Soal Nomor 24 mengenai Konsep Medium Rambatan Bunyi}

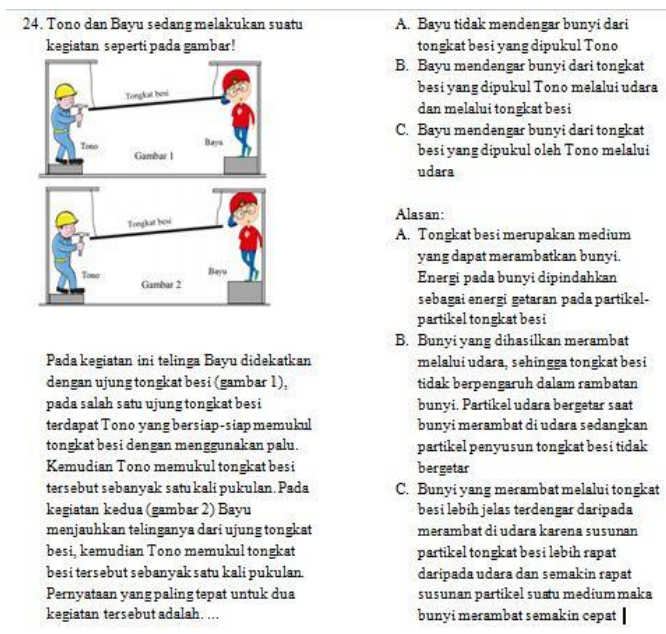

Hasil analisis jawaban menunjukkan sebanyak 42,6\% siswa mengalami false positive. Siswa beranggapan bahwa bunyi merambat melalui udara sehingga tongkat besi tidak berpengaruh dalam rambatan bunyi. Teridentifikasi anggapan siswa bahwa bunyi tidak dapat merambat melalui medium padat. Anggapan ini menunjukkan adanya kesalahan konsep siswa dan memerlukan adanya pembuktian dalam praktikum mandiri oleh siswa sehingga siswa akan memperbaiki konsepnya dengan benar.

Konsep yang seharusnya dimiliki siswa yakni bahwa bunyi dapat merambat melalui medium zat padat dan bunyi tidak dapat merambat di ruang hampa udara. Bunyi merupakan gelombang mekanik yang membutuhkan medium dalam rambatannya. Medium rambatan dapat berupa zat cair, zat padat dan gas. Semakin besar kerapatan medium maka semakin cepat rambat bunyi karena semakin cepatnya perpindahan energi pada medium (Serway \& Jewett, 2010).

Berdasarkan hasil identifikasi miskonsepsi pada setiap butir konsep, berikut daftar miskonsepsi yang dialami siswa ditunjukkan pada Tabel 3.2.

Tabel 3.2 Daftar Miskonsepsi Siswa pada Materi Getaran dan Gelombang

\begin{tabular}{|l|l|c|}
\hline \multicolumn{2}{|l|}{ Miskonsepsi } & \% Siswa \\
\hline Getaran & $\begin{array}{l}\text { Semakin panjang tali bandul maka periode getaran bandul } \\
\text { semakin kecil }\end{array}$ & 13,89 \\
\hline$(1)$ & $\begin{array}{l}\text { Perubahan massa bandul mempengaruhi perubahan periode } \\
\text { getaran bandul }\end{array}$ & 32,41 \\
\hline Besaran Gelombang & $\begin{array}{l}\text { Panjang gelombang adalah simpangan antara puncak } \\
\text { gelombang dengan puncak gelombang yang bersebelahan }\end{array}$ & 11,90 \\
\hline$(3)$ & $\begin{array}{l}\text { Panjang gelombang adalah jarak antara pusat rapatan ke pusat } \\
\text { renggangan yang berurutan }\end{array}$ & 5,56 \\
\hline
\end{tabular}




\begin{tabular}{|l|l|c|}
\hline$(5)$ & $\begin{array}{l}\text { Panjang gelombang adalah jarak antara dua partikel dalam } \\
\text { kondisi tidak terganggu }\end{array}$ & 2,91 \\
\hline$(6)$ & $\begin{array}{l}\text { Amplitudo gelombang adalah jarak pusat rapatan ke pusat } \\
\text { renggangan }\end{array}$ & 5,56 \\
\hline Gerak Gelombang & 40,12 \\
\hline$(7)$ & $\begin{array}{l}\text { Gelombang dalam perambatannya memindahkan materi } \\
\text { sehingga partikel mediumnya terdorong ke segala arah dari } \\
\text { sumber gelombang }\end{array}$ & 9,72 \\
\hline Cepat Rambat Gelombang & $\begin{array}{l}\text { Semakin besar frekuensi bunyi maka cepat rambat gelombang } \\
\text { semakin cepat pada medium yang sama }\end{array}$ & 13,66 \\
\hline$(8)$ & $\begin{array}{l}\text { Semakin besar massa jenis tali maka cepat rambat gelombang } \\
\text { semakin cepat dan frekuensi pada tali semakin besar }\end{array}$ & 13,89 \\
\hline$(9)$ & $\begin{array}{l}\text { Jika tegangan tali dan massa jenis tali tetap, frekuensi } \\
\text { ditambahkan maka cepat rambat gelombang tali semakin cepat }\end{array}$ & 3,47 \\
\hline$(10)$ & $\begin{array}{l}\text { Semakin pendek tali maka cepat rambat gelombang tali semakin } \\
\text { cepat karena massa jenis tali menjadi lebih kecil dan tegangan } \\
\text { tali tetap }\end{array}$ & 24,54 \\
\hline Medium Rambatan Bunyi & 10,19 \\
\hline$(12)$ & Bunyi tidak dapat merambat pada medium zat padat \\
\hline$(13)$ & Bunyi dapat merambat di ruang hampa udara & \\
\hline
\end{tabular}

berdasarkan tabel 3.2 dapat diketahui bahwa siswa mengalami miskonsepsi terbanyak yakni $40,12 \%$. Miskonsepsi siswa yakni gelombang yang dalam perambatannya memindahkan materi sehingga partikel mediumnya terdorong ke segala arah dari sumber gelombang.

\section{Simpulan}

\subsection{Kesimpulan}

Berdasarkan analisis hasil penelitian dapat disimpulkan bahwa temuan miskonsepsi siswa pada materi getaran dan gelombang, antara lain:

4.1.1. Siswa beranggapan bahwa periode getaran bandul dipengaruhi oleh massa bandul.

4.1.2. Siswa beranggapan bahwa panjang gelombang adalah simpangan antara puncak gelombang dengan puncak gelombang yang bersebelahan.

4.1.3. Siswa beranggapan bahwa gelombang dalam perambatannya memindahkan materi sehingga partikel mediumnya terdorong ke segala arah dari sumber gelombang.

4.1.4. Siswa beranggapan bahwa cepat rambat gelombang semakin cepat ketika massa jenis tali semakin besar atau frekuensi ditambahkan sedang tegangan tali dan massa jenis tali, tetap.

Siswa beranggapan bahwa bunyi dapat merambat pada medium zat padat dan di ruang hampa. 


\subsection{Saran}

Berdasarkan kesimpulan dan implikasi hasil penelitian ini, maka peneliti memiliki beberapa saran, antara lain:

1.1.1. Adanya remedial pada konsep getaran dan gelombang serta penerapannya untuk memperbaiki konsepsi siswa menjadi benar.

1.1.2. Perlu adanya diagnostic test pada siswa setelah proses pembelajaran untuk mengetahui letak miskonsepsi siswa.

1.1.3. Guru perlu menambah variasi tindakan dalam praktikum mandiri siswa di konsep getaran, besaran gelombang transversal, besaran gelombang longitudinal, gerak gelombang, cepat rambat gelombang tali, cepat rambat gelombang terhadap jarak dan waktu tempuh gelombang untuk menambah data pembanding yang dimiliki siswa sehingga memudahkan siswa dalam mengenal konsep yang benar.

\section{Daftar Rujukan}

Abbas, M. L. H. (2016). Pengembangan instrumen three tier diagnostic test miskonsepsi suhu dan kalor. EdHumanistics: Jurnal Ilmu Pendidikan, 1(2).

Dewi, I. N. A., Kusairi, S., \& Yuliati, L. (2016). Miskonsepsi Siswa SMA pada Materi Hukum Archimedes. In Prosiding Seminar Nasional Tahun.

Gurel, D. K., Eryılmaz, A., \& McDermott, L. C. (2015). A review and comparison of diagnostic instruments to identify students' misconceptions in science.

Istiqomah, N. (2017). Analisis Miskonsepsi Pokok Bahasan Gelombang Mekanik pada Siswa Kelas XII SMAN Kencong. Seminar Nasional Pendidikan Fisika FKIP, Universitas Jember 2017 Vol.2, ISSN : 2527 - 5917

Liza, M. M., Soewarno, S., \& Marwan, A. R. (2016). Identifikasi Miskonsespi Siswa pada Materi Getaran dan Gelombang Kelas VIII di Mtsn Rukoh. Jurnal Ilmiah Mahasiswa Pendidikan Fisika, 1(4), 212-217.

Marlina, M., Utaya, S., \& Yuliati, L. (2017, May). Penguasaan Konsep IPA Pada Siswa Sekolah Dasar Negeri (SDN) Penanggungan Malang. In Seminar Nasional Teknologi Pembelajaran dan Pendidikan Dasar 2017 (pp. 781-787).

Peşman, H. (2005). Development of a three-tier test to assess ninth grade students' misconceptions about simple electric circuits (Master's thesis).

Peşman, H., \& Eryılmaz, A. (2010). Development of a three-tier test to assess misconceptions about simple electric circuits. The Journal of educational research, 103(3), 208-222.

Kemdiknas, P. (2019). Laporan Hasil Ujian Nasional Tahun Pelajaran 2018/2018. Jakarta: Puspendik.

Ratnaningdyah, D. (2018, July). Mengungkap miskonsepsi fisika dengan metode the three-tier test. In prosiding seminar nasional program pascasarjana universitas pgri palembang (Vol. 5, No. 05).

Sarlina, S. (2015). Miskonsepsi Siswa terhadap Pemahaman Konsep Matematika pada Pokok Bahasan Persamaan Kuadrat Siswa Kelas X5 SMA Negeri 11 makassar. MaPan: Jurnal Matematika dan Pembelajaran, 3(2), 194-209.

Serway, R., \& Jewett, J. (2009). Physics for Scientists and Engineers, Chapters 1-39. Nelson Education.

Shalihah, A., Mulhayatiah, D., \& Alatas, F. (2016). Identifikasi Miskonsepsi Menggunakan Tes Diagnostik Three-tier Pada Hukum Newton Dan Penerapannya. Journal of Teaching and Learning Physics, 1(1), 24-33.

YAQIN, M. (2018). Pengembangan Instrumen Tes Diagnostik Three-tier Konsep Getaran dan Gelombang untuk Mengidentifikasi Miskonsepsi Siswa SMP Kelas VIII. Skripsi prodi pendidikan ipa-fakultas MIPA $U M$.

Zayyinah, Z., Munawaroh, F., \& Rosidi, I. (2018). Identifikasi Miskonsepsi Siswa SMP Dengan Certainty Of Response Index (CRI) Pada Konsep Suhu dan Kalor. Natural Science Education Research, 1(2), 78-89. 